\title{
Thermal Decomposition Kinetics of Humic Substances Extracted from Mid-Rio Negro (Amazon Basin) Soil Samples
}

\author{
Luciana Camargo de Oliveira, ${ }^{* a}$ Clovis Augusto Ribeiro, ${ }^{a}$ André Henrique Rosa, ${ }^{b}$ Wander Gustavo \\ Botero, ${ }^{a, c}$ Julio Cesar Rocha, ${ }^{a}$ Luciane Pimenta Cruz Romão ${ }^{d}$ and Ademir dos Santos ${ }^{a}$
}

\author{
anstituto de Química de Araraquara, Universidade Estadual Paulista, CP 355, 14800-900 Araraquara-SP, Brazil \\ ${ }^{b}$ Departmento de Engenharia Ambiental, Universidade Estadual Paulista, 18087-180 Sorocaba-SP, Brazil \\ 'Universidade Federal de Alagoas, Arapiraca, CP 61, 57309-005 Arapiraca-AL, Brazil \\ ${ }^{d}$ Departamento de Química, Universidade Federal de Sergipe, 49100-000 São Cristovão-SE, Brazil
}

\begin{abstract}
Neste trabalho substâncias húmicas (SH) extraídas de solos não alagáveis (Araçá) e alagáveis (Iara) foram caracterizadas com cálculos de estabilidade e energias de ativação associadas com a desidratação e decomposição térmica de SH utilizando TGA and DTA, ressonância paramagnética eletrônica (EPR) e razões atômicas $\mathrm{C} / \mathrm{H}, \mathrm{C} / \mathrm{N}$ e C/O. Para SH extraídas de solos alagáveis, existe evidências da influência da umidade sobre o processo de humificação da matéria orgânica. Observações do comportamento térmico, com análise elementar, indicaram a presença de fósseis de carbono orgânico nas partículas de argila, o que só decompõe acima de $800^{\circ} \mathrm{C}$. Essa característica pode explicar as diferentes estabilidades térmicas e energias de ativação requeridas na pirólise para amostra Iara comparada a amostra Araçá.
\end{abstract}

In this work humic substances (HS) extracted from non-flooded (Araçá) and flooded (Iara) soils were characterized through the calculation of stability and activation energies associated with the dehydration and thermal decomposition of HS using TGA and DTA, electronic paramagnetic resonance and $\mathrm{C} / \mathrm{H}, \mathrm{C} / \mathrm{N}$ and $\mathrm{C} / \mathrm{O}$ atomic ratios. For $\mathrm{HS}$ extracted from flooded soils, there was evidence for the influence of humidity on the organic matter humification process. Observations of thermal behaviour, with elemental analysis, indicated the presence of fossilized organic carbon within clay particles, which only decomposed above $800^{\circ} \mathrm{C}$. This characteristic could explain the different thermal stability and pyrolysis activation energies for Iara HS compared to Araçá HS.

Keywords: soils, humic substances, kinetics, thermal analysis, Amazon

\section{Introduction}

The Amazon area occupies approximately $6,000,000 \mathrm{~km}^{2}$ of South America, corresponding to almost $50 \%$ of Brazil's national territory. This region is characterized by a great variety of soil types, flooded and non-flooded zones, and white (particle-laden) and black (humic substances-rich) waters, with unique features of biodiversity, temperature and humidity. An important factor in this area is the high concentration of organic matter present within aquatic and terrestrial systems.

The greatest mass of refractory organic carbon present in soils and aquatic systems is in the form of humic substances (HS). These are a polydisperse mixture of

*e-mail: lcamargo@iq.unesp.br macromolecules produced by microbial degradation of vegetation and animal residues. HS exert important functions in aquatic and terrestrial systems due to the diversity of the functional groups present in their structures. In soils they occur mainly as insoluble macromoleculal aggregates, linked via di- and tri-valent cations and/or in associations with mineral clay through cationic bridges, hydrogen bonds and ligand exchange reactions.

Humic substances extracted from different types of soils differ in their physical characteristics and chemistries due to their genesis via diverse humification mechanisms. Hence different techniques have been used for their structural characterization, such as measurement of the $\mathrm{E}_{4} / \mathrm{E}_{6}$ ratio, defined as the ratio of optical absorbance at 465 and $665 \mathrm{~nm}$ in aqueous solutions, ${ }^{1}$ carbon-13 nuclear magnetic resonance, ${ }^{2}$ fluorescence emission 
spectroscopy, ${ }^{3,4}$ atomic ratios of the elements carbon, hydrogen, nitrogen and oxygen $(\mathrm{C} / \mathrm{H}, \mathrm{C} / \mathrm{N} \text { and } \mathrm{C} / \mathrm{O})^{5}$ and electronic paramagnetic resonance. ${ }^{3,6,7} \mathrm{The}$ spectroscopic techniques have been most widely used for structural characterization of HS.

Thermal analyses, mainly thermogravimetric analysis (TGA) and differential thermal analysis (DTA), have shown promise for studies associated with the behaviour of soils in the environment. ${ }^{8}$ However few studies have been reported in the literature concerning use of thermal analysis for characterization of HS, with calculation of the activation energy via non-isothermal procedures.

Humic substances extracted from flooded and non-flooded soils of the Amazon basin have similarly been little studied, especially in relation to their structural characteristics. Hence in this work HS extracted from a complex non-flooded soil (Araçá) and a flooded soil (Iara), possessing different mineralogical compositions, were characterized through the calculation of stability and activation energies associated with their dehydration and thermal decomposition, using TGA and DTA, electronic paramagnetic resonance (EPR) and $\mathrm{C} / \mathrm{H}, \mathrm{C} / \mathrm{N}$ and $\mathrm{C} / \mathrm{O}$ atomic ratios.

\section{Experimental}

\section{Chemicals and reagents}

All reagents used were of high-purity grade unless otherwise stated. The acid and alkaline solutions necessary for HS isolation were prepared by dilution of $30 \%$ hydrochloric acid (Merck AG) or dissolution of sodium hydroxide-monohydrate (Merck AG) in high-purity water (Milli-Q system, Millipore).

\section{Soil sampling}

The Amazonian soils under study (Table 1) were collected from the Negro river basin (state of Amazonas, Brazil), between the towns of Barcelos and Santa Izabel. Soils were transferred to wooden trays and dried in a recirculating air oven at $25^{\circ} \mathrm{C}$. Dried soils were then passed through a $2 \mathrm{~mm}$ plastic sieve and stored in polyethylene bags.

Table 1. Pedologic classification, location and characteristics of soil sampling sites in the Rio Negro basin, Amazonas State, Brazil

\begin{tabular}{lccc}
\hline Samples & $\begin{array}{c}\text { Pedologic } \\
\text { classification }\end{array}$ & Location & $\begin{array}{c}\text { Characteristics of the } \\
\text { collection sites }\end{array}$ \\
\hline Iara (I) & Gley (humic) & $\begin{array}{c}\text { S01 } 20.01^{\circ} \\
\mathrm{W}^{\circ} 2^{\circ} 03.81^{\prime}\end{array}$ & $\begin{array}{c}\text { Near Iara lake, region under } \\
\text { dark floodwaters }\end{array}$ \\
Araçá (A) & $\begin{array}{c}\text { Podzolic } \\
\text { (red yellow) }\end{array}$ & $\begin{array}{c}\mathrm{S}^{\circ} 1^{\circ} 14.00^{\prime} \\
\mathrm{W}^{\circ} 61^{\circ} 50.00^{\prime}\end{array}$ & $\begin{array}{c}\text { Near Araçá lake, unflooded } \\
\text { region }\end{array}$ \\
\hline
\end{tabular}

\section{Humic substance extractions}

The HS were extracted according to the procedure recommended by the International Humic Substances Society. ${ }^{9,10}$ For this purpose, $50 \mathrm{~g}$ of the soil samples were extracted using a volume of $0.1 \mathrm{~mol} \mathrm{~L}^{-1} \mathrm{HCl}$ equal to ten times the weight of the sample. The $\mathrm{pH}$ of the solution was adjusted to between 1.0 and 2.0 with $1.0 \mathrm{~mol} \mathrm{~L}^{-1} \mathrm{HCl}$. The soil $/ \mathrm{HCl}$ mixture was shaken for $1 \mathrm{~h}$ and the suspension allowed to settle. The mixture was then centrifuged at $1478 \mathrm{~g}$ for $10 \mathrm{~min}$, and the supernatant was separated from the sediment. The sediment was neutralized with $1.0 \mathrm{~mol} \mathrm{~L}^{-1}$ $\mathrm{NaOH}$ to $\mathrm{pH} 7.0$, and a volume of $0.1 \mathrm{~mol} \mathrm{~L}^{-1} \mathrm{NaOH}$ equal to ten times the weight of the sample was added under a nitrogen atmosphere. The mixture was shaken for $4 \mathrm{~h}$ and then allowed to settle overnight. The supernatant was separated from the sediment by centrifugation at $1478 \mathrm{~g}$ for $10 \mathrm{~min}$, and the sediment discarded. The supernatant (containing the HS) was evaporated under vacuum and dried in a recirculating air oven at $55^{\circ} \mathrm{C}$ in order to estimate the percentage of HS in the soils.

\section{Characterization of humic substances}

\section{Thermal behavior}

TGA and DTA curves were obtained using a TA Instruments Model SDT 2960 analyzer with an alumina pan, a sample mass of around $8 \mathrm{mg}$, an atmosphere of synthetic air $\left(80 \% \mathrm{~N}_{2}\right.$ and $\left.20 \% \mathrm{O}_{2}\right)$ or nitrogen at a flow rate of $100 \mathrm{~mL} \mathrm{~min}^{-1}$, and a heating rate of $10{ }^{\circ} \mathrm{C} \mathrm{min}^{-1}$.

Using non-isothermal TGA procedures, the thermal decomposition of a material can be mathematically described by the kinetic triplet $(E, \log A$ and $f(\alpha)$ ). A solid-state Arrhenius type reaction can be expressed by the general equation: ${ }^{11-14}$

$\frac{\mathrm{d} \alpha}{\mathrm{dT}}=\frac{\mathrm{A}}{\beta} \exp \left(\frac{-\mathrm{E}}{\mathrm{RT}}\right) \mathrm{f}(\alpha)$

where the fractional degradation $(\alpha)$ is temperature $(T)$ dependent during an increasing constant heating rate $(\beta)$. According to the isoconversional Flynn-Wall-Ozawa (F-W-O) method, the angular and line ar coefficients and constant $\alpha$ of a plot of $\log \beta$ versus $1 / \mathrm{T}$ at different temperatures gives E. ${ }^{11-14}$

\section{Elemental analysis}

Elemental analyses of the extracted HS were undertaken using a Thermo-Finnegan elemental analyzer.

Electron Paramagnetic Resonance (EPR) Spectroscopy

The EPR measurements were performed in a Bruker 
EMX spectrometer operating at X-Band (9 GHz), with a rectangular cavity, at room temperature. The experimental parameters were: $0.2 \mathrm{~mW}(30 \mathrm{~dB})$ microwave power (obtained from the microwave power saturation curve), ${ }^{15}$ $100 \mathrm{kHz}$ modulation frequency, $0.1 \mathrm{mT}$ modulation amplitude, with minimum 4 scans accumulated. For quantitative analysis, quartz EPR tubes (2.5 mm I.D.) were filled with the sample, taking into account the mass concentration. The relative areas of EPR signals were obtained by the approximation $\mathrm{I} \times \Delta \mathrm{H}^{2,16}$ where $\mathrm{I}$ is the EPR derivative signal amplitude and $\Delta \mathrm{H}^{2}$ the peak-to-peak line width. The relative concentration of semiquinone-type free radicals (spin concentration) was obtained using as a secondary standard a ruby crystal calibrated with a strong pitch reference of known free radical content, according to Singer's method. ${ }^{17,18}$ The HS samples were dried in desiccators over silica gel and the results obtained were corrected for the sample's carbon content (spins $\left(\mathrm{g} \mathrm{C}^{-1}\right)$.

\section{Results and Discussion}

According to Wershaw, ${ }^{19}$ in soils and sediments the humus comprises aggregates consisting of organic matter in the form of double layer membranes coating the mineral grains. These aggregates are formed during humification, the process during which residues of plants and animals are converted into humus, a basic stage of the carbon cycle. The organic components of animal and plant tissues are thermodynamically unstable in an oxidizing atmosphere and, during decomposition, are converted to $\mathrm{CO}_{2}$ and water in degradation reactions catalysed by enzymes secreted by microorganisms. However not all of these animal and plant residues achieve full mineralization, and a fraction can accumulate in the form of humus. Humus produced in soils is comprised of amphiphilic molecules, products of the degradation of plants and lignin carbohydrate complexes, which interact with mineral grains present in the soils. This interaction results in the formation of membranes of amphiphilic molecules on the mineral grains.

The optimum method for measuring the extent of humification remains a debatable question, since there is no well-defined model of HS structure..$^{20}$ However, it is usually evaluated through indirect measurements which reflect the structural changes occurring during the humification process. Several techniques have been used to characterize the progress of humification, including measurement of the $\mathrm{E}_{4} / \mathrm{E}_{6}$ ratio, defined as the ratio of optical absorbance at 465 and $665 \mathrm{~nm}$ in aqueous solution, which indicates structural condensation, ${ }^{21,1}$ aromatic $\mathrm{C}$, determined by CPMAS ${ }^{13} \mathrm{C}$ Nuclear Magnetic Resonance (NMR) ${ }^{22}$ and $\mathrm{C} / \mathrm{H}, \mathrm{C} / \mathrm{O}$, and $\mathrm{C} / \mathrm{N}$ ratios, defined as the atomic ratio between these elements (carbon, hydrogen, oxygen, and nitrogen). ${ }^{1,9}$ A more specific molecular spectroscopic technique to estimate the degree of humification in soil organic matter is the concentration of stable free radicals (semiquinone-type obtainable by electron paramagnetic resonance (EPR))., 3,67 Complex aromatic structures are believed to stabilize free radicals in $\mathrm{HS}^{1,23} \mathrm{In}$ this paper $\mathrm{C} / \mathrm{H}, \mathrm{C} / \mathrm{N}$ and $\mathrm{C} / \mathrm{O}$ atomic ratios, and concentrations of free radicals, were used to measure the degree of humification of humic substances.

Table 2. Atomic ratios $(\mathrm{C} / \mathrm{H}, \mathrm{C} / \mathrm{N}$ and $\mathrm{C} / \mathrm{O})$ and spin concentrations for humic substances extracted from mid-Rio Negro basin soils

\begin{tabular}{lcccc}
\hline Sample & \multicolumn{3}{c}{ Atomic ratio } & $\begin{array}{c}\text { Spin concentration / } \\
\left(10^{18} \mathrm{~g}^{-1}\right)\end{array}$ \\
\hline HS-A & $\mathrm{C} / \mathrm{H}$ & $\mathrm{C} / \mathrm{N}$ & $\mathrm{C} / \mathrm{O}$ & $0.32 \pm 0.02$ \\
HS-I & 0.54 & 12.43 & 0.93 & $0.91 \pm 0.03$ \\
\hline
\end{tabular}

HS spin concentrations were in the range 3.2-9.1 $\times 10^{17}$ spins $(\mathrm{g} \mathrm{C})^{-1}$ (Table 2), indicating substantial differences in the humification levels of HS extracted from Amazonian soils. These values are relatively high in comparison with the results reported by Swift, ${ }^{24}$ but are comparable to values obtained for more humified samples. ${ }^{7,18}$ In addition, it was observed that HS extracted from soils in flooded regions (Iara sample) possessed higher spin concentrations than HS extracted from soils in non-flooded regions (Araçá). The higher spin concentration in flooded soil could be a consequence of the anoxic environment as semiquinones and other organic free radical contents increase under reductive condition. These findings indicate that humidity affects the humification process, as observed earlier by Martin-Neto et al., ${ }^{7}$ who found a good correlation between the spin concentration in HS and annual mean precipitation.

Decomposition of organic material in soil tends to lead to the formation of phenolic structures deriving from lignin, whose rates of decomposition differ from those of other organics (such as sugars and proteins). ${ }^{25}$ Hence $\mathrm{C} / \mathrm{H}, \mathrm{C} / \mathrm{N}$, and $\mathrm{C} / \mathrm{O}$ atomic ratios have been used as important indicators of the aromaticity and extent of organic material decomposition. According to the literature, ${ }^{1}$ higher values of $\mathrm{C} / \mathrm{H}, \mathrm{C} / \mathrm{O}$, and $\mathrm{C} / \mathrm{N}$ atomic ratios are associated with higher degrees of humification due to decreased carbohydrate and amino acid / protein contents. Hence the fact that the sample collected in the flooded area showed higher atomic ratios indicated a greater extent of humification, in agreement with the EPR data. This is probably related to the nature of the sampling point, in a more anoxic area where organic matter cycling is reduced. Hence anoxia in the flooded areas directly influences the degree of humification of HS. 

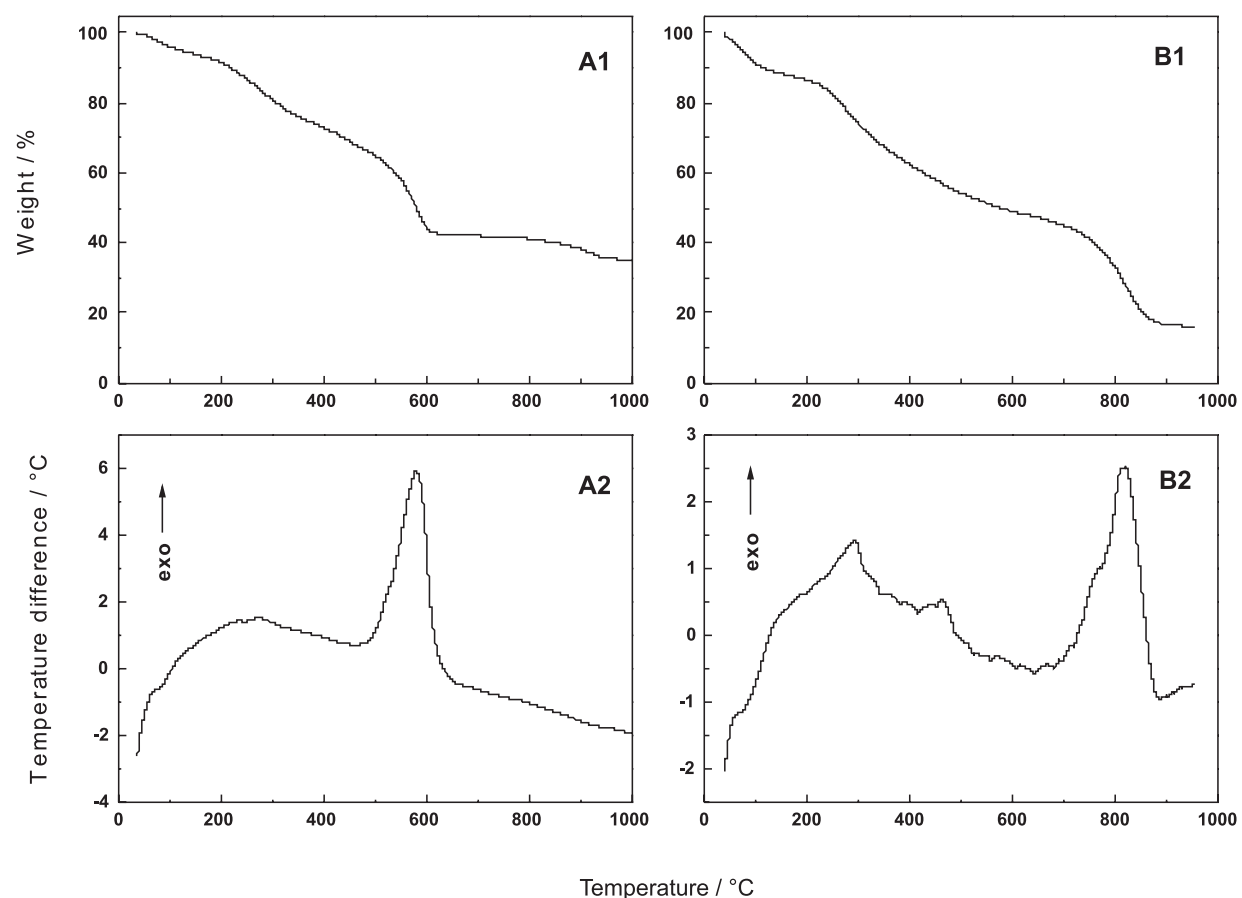

Figure 1. TGA and DTA curves for humic substances extracted from (A1, A2) Araça and (B1, B2) Iara soils. Conditions: Air atmosphere (100 mL min $\left.{ }^{-1}\right)$, $10{ }^{\circ} \mathrm{C} \min ^{-1}$ heating rate, alumina pan.

TGA and DTA curves obtained under a synthetic air atmosphere (Figure 1) illustrate the differences in thermal behaviour between the humic substances extracted from Iara and Araçá soils.

From the TGA and DTA curves for Araça HS (Figure 1, $\mathrm{A}_{1}$ and $\mathrm{A}_{2}$ ), mass loss features between 40 and $650^{\circ} \mathrm{C}$ can be attributed to the dehydration and thermal decomposition of HS resulting in a mineralised residue consisting mainly of clay minerals plus oxides and / or carbonates formed during the decomposition of the organic matter. The DTA curve (Figure 1- $\mathrm{A}_{2}$ ) shows small endothermic and exothermic peaks up to $400{ }^{\circ} \mathrm{C}$ and a sharp peak around $580^{\circ} \mathrm{C}$, corresponding to the TGA curve (Table 3 ).

From the TGA and DTA curves for Iara HS (Figure 1, $\mathrm{B}_{1}$ and $\mathrm{B}_{2}$ ), the mass loss up to $627^{\circ} \mathrm{C}$ is attributed to dehydration and thermal decomposition, with corresponding exothermic peaks in the DTA curve, however the thermal behaviour differs from that observed for Araçá HS. Between 627 and $954^{\circ} \mathrm{C}$, a $32 \%$ mass loss was accompanied by a corresponding sharp exothermic peak in the DTA curve, indicative of the decomposition of organic carbon which had been incorporated within the matrix during clay formation.

Hence for Iara soil, but not for Araçá soil, there is evidence for the presence of organic carbon fossilized within the clay, which was later covered with humic substances, suggesting that this may be a characteristic of material originating from flooded areas. The reaction between 627 and $954^{\circ} \mathrm{C}$ occurs during the phase transition of clay from crystalline to amorphous $\left(800-1000^{\circ} \mathrm{C}\right)$, which exposes the fossilized organic carbon to the oxidizing atmosphere. ${ }^{8} \mathrm{CHN}$ analysis of Iara HS (Table 4) indicated the presence of $35.5 \%$ of carbon in calcined residue, further supporting this hypothesis.

TGA and DTA curves for Araçá and Iara HS obtained under nitrogen atmospheres (Figure 2) illustrate differences in thermal behaviour, both between soils and relative to their behaviours under air atmospheres, however with similar mass losses up to approximately $600^{\circ} \mathrm{C}$ (Table 3 ).

From the TGA and DTA curves obtained under nitrogen atmospheres (Figure 2), behaviour between 40 and $400{ }^{\circ} \mathrm{C}$ was indicative of three stages of mass loss for Araçá HS, and two stages for Iara HS. The events correspond to peaks P1, P2 (and P3) in the DTA curves. From the DTA peak intervals the activation energies, $\mathrm{E}(\alpha)$, relative to the reaction fraction, $\alpha$, for non-isothermal processes were calculated according to the method of Flynn-WallOzawa. Graphs of E $(\alpha)$ versus $\alpha$ (Figure 3) indicate the different pyrolysis/dehydration behaviours of Araçá and Iara HS. Table 5 shows maximum values of the functions $\mathrm{y}(\alpha)$ and $\mathrm{z}(\alpha)$ against $\alpha$, for DTA dehydration and thermal decomposition peaks 1-3 (HS-A) and 1-2 (HS-I).

The two pyrolysis / dehydration reactions evaluated for Iara HS (Figure 3B) indicate more homogeneous events, with smaller activation energies, compared to Araçá HS, with activation energies of around $60 \mathrm{~kJ} \mathrm{~mol}^{-1}$ for P1 

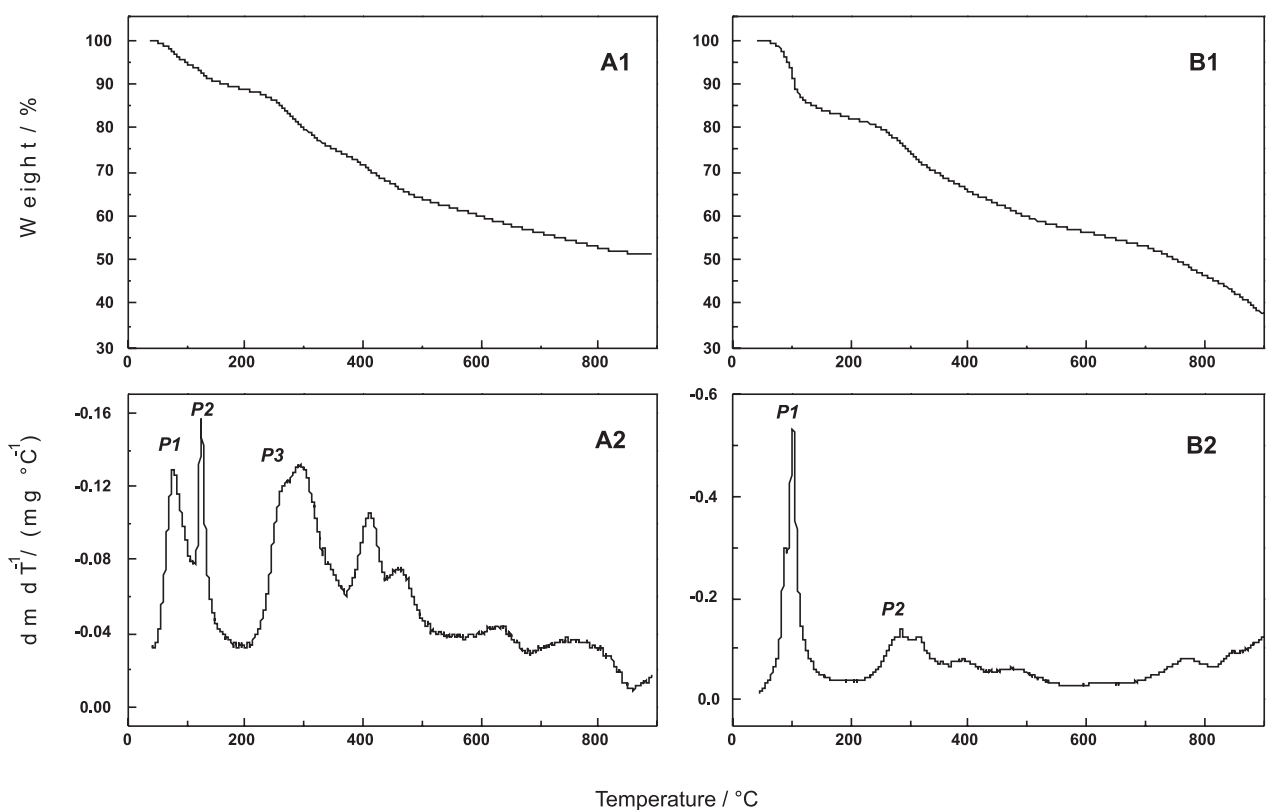

Figure 2. TGA and DTA curves for humic substances extracted from (A1, A2) Araça and (B1, B2) Iara soils. Conditions: $\mathrm{N}_{2}$ atmosphere (100 mL min ${ }^{-1}$ ), $10{ }^{\circ} \mathrm{C} \mathrm{min}^{-1}$ heating rate, alumina pan.

Table 3. Data from TGA and DTA curves (Figures 2-3) for humic substances extracted from Araça (HS-A) and Iara (HS-I) soils

\begin{tabular}{|c|c|c|c|c|c|c|c|}
\hline \multicolumn{4}{|c|}{ TGA curves } & \multicolumn{4}{|c|}{ DTA curves / $\left({ }^{\circ} \mathrm{C}\right)$} \\
\hline \multicolumn{2}{|c|}{ Air atmosphere } & \multicolumn{2}{|c|}{$\mathrm{N}_{2}$ atmosphere } & \multicolumn{2}{|c|}{ Air atmosphere / peak } & \multicolumn{2}{|c|}{$\mathrm{N}_{2}$ atmosphere / peak } \\
\hline$\Delta \mathrm{m} /(\%)$ & $\Delta \mathrm{T} /\left({ }^{\circ} \mathrm{C}\right)$ & $\Delta \mathrm{m} /(\%)$ & $\Delta \mathrm{T} /\left({ }^{\circ} \mathrm{C}\right)$ & Endo & Exo & Endo & Exo \\
\hline \multicolumn{8}{|c|}{ HS-I } \\
\hline \multirow[t]{3}{*}{12.46} & $40-173$ & 17.06 & $40-190$ & 73 & & 107 & \\
\hline & & 14.13 & $190-368$ & & 292 & 322 & \\
\hline & & 4.50 & $368-435$ & & & & \\
\hline \multirow[t]{2}{*}{39.45} & $173-627$ & 6.44 & $435-576$ & & 463 & & \\
\hline & & 11.61 & $576-820$ & & 771,819 & & \\
\hline 31.88 & $627-954$ & 16.86 & $820-991$ & & & & \\
\hline 16.21 (residue) & 954 & 27.28 (residue) & 991 & & & & \\
\hline \multicolumn{8}{|c|}{ HS-A } \\
\hline \multirow[t]{2}{*}{6.41} & $40-158$ & 5.61 & $40-112$ & 85 & & 83 & \\
\hline & & 4.62 & $112-192$ & & & 130 & \\
\hline 20.19 & $158-393$ & 14.32 & $192-371$ & & 236,275 & & 254 \\
\hline 7.56 & $393-489$ & 5.37 & $371-440$ & & & 422 & \\
\hline \multirow[t]{2}{*}{23.75} & $489-661$ & 5.59 & $440-544$ & & 580 & & \\
\hline & & 5.11 & $544-685$ & & & 637 & \\
\hline 6.86 & $738-1000$ & 4.78 & $685-890$ & & & & \\
\hline 35.27 (residue) & 1000 & 48.08 (residue) & 890 & & & & \\
\hline
\end{tabular}

Table 4. Elemental analysis of humic substances extracted from mid-Rio Negro basin soils

\begin{tabular}{lcccccc}
\hline \multirow{2}{*}{ Compounds } & \multicolumn{3}{c}{ Initial } & \multicolumn{3}{c}{ Calcined residue } \\
& $\mathrm{C}$ & $\mathrm{H}$ & $\mathrm{N}$ & $\mathrm{C}$ & $\mathrm{H}$ & $\mathrm{N}$ \\
\hline HS-A & 24.70 & 3.28 & 2.14 & nd & 0.28 & 1.10 \\
HS-I & 26.20 & 3.84 & 1.77 & 35.54 & 1.24 & 1.70 \\
\hline
\end{tabular}

and $150 \mathrm{~kJ} \mathrm{~mol}^{-1}$ for P2. For Araçá HS (Figure 3A) the relationship $\mathrm{E}$ versus $\alpha$ is suggestive of the occurrence of a greater number of reactions than indicated by $\mathrm{P} 1, \mathrm{P} 2$ and P3. For the interval which includes these peaks, the initial activation energy (at P1) is around $120 \mathrm{~kJ} \mathrm{~mol}^{-1}$, increasing to $140 \mathrm{~kJ} \mathrm{~mol}^{-1}$ at the beginning of $\mathrm{P} 2$ and then increasing continuously to $240 \mathrm{~kJ} \mathrm{~mol}^{-1}$, and remaining around this value for the reaction corresponding to $\mathrm{P} 3$.

This behaviour is indicative that $(\alpha)$ there are larger heterogeneities in the decomposition of Araçá HS than of Iara HS, and $(\beta)$ the clay-carbon support in Iara HS acts as a catalyst during the thermal decomposition of HS. 
Table 5. Maximum values of the $y(\alpha)$ and $z(\alpha)$ functions against $\alpha$ for the DTA dehydration and thermal decomposition peaks 1-3 (HS-A) and 1-2 (HS-I)

\begin{tabular}{lccccccc}
\hline \multirow{2}{*}{ Compound } & \multicolumn{2}{c}{ Peak 1 } & \multicolumn{2}{c}{ Peak 2 } & \multicolumn{2}{c}{ Peak 3 } \\
& $\alpha_{\mathrm{y}}^{*}$ & $\alpha_{\mathrm{z}}^{*}$ & $\alpha_{\mathrm{y}}^{*}$ & $\alpha_{\mathrm{z}}{ }^{*}$ & $\alpha_{\mathrm{y}}^{*}$ & $\alpha_{\mathrm{z}}{ }^{*}$ \\
\hline HS-A $_{(0-10)}$ & 0.05 & 0.41 & 0.33 & 0.51 & 0.13 & 0.56 \\
HS-I $_{(0-10)}$ & 0.41 & 0.49 & 0.21 & 0.53 & - & - \\
\hline
\end{tabular}
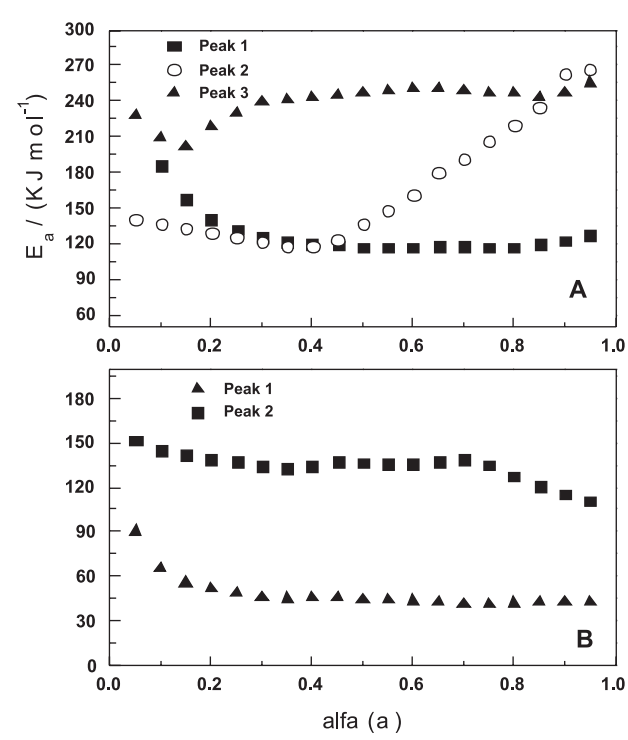

Figure 3. Activation energy ( $\left.E_{a}\right)$ against alpha for (A) HS-A and (B) HS-I.

Evaluating the intra-relationship of the results of $\mathrm{E} x \alpha$ in relation to the kinetic compensation effect (KCE), $\ln \mathrm{A}=\mathrm{a}+\mathrm{bE}$, the behaviour illustrated in Figure 4 is obtained for the peak intervals of Araçá and Iara HS samples.

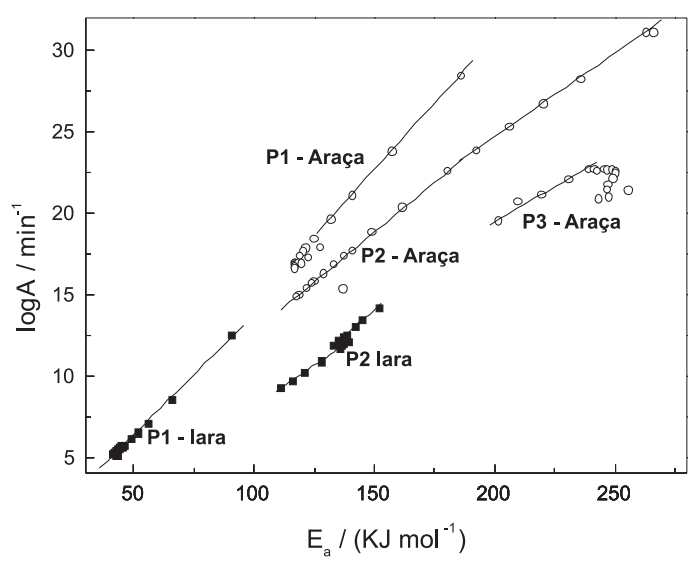

Figure 4. Kinetic compensation effect (KCE).

\section{Conclusions}

Spin concentration data indicate large differences between the degrees of humification of HS extracted from different Amazon soils. HS extracted from flooded soil showed higher spin concentrations than HS extracted from non-flooded soil, indicating the influence of humidity on the organic matter humification process. $\mathrm{C} / \mathrm{H}, \mathrm{C} / \mathrm{N}$ and $\mathrm{C} / \mathrm{O}$ atomic ratios corroborated the EPR data, also suggesting a greater extent of humification for extracts of samples collected from flooded areas. It can therefore be inferred that anaerobic conditions exert a strong influence on the humification process within flooded soils of the Rio Negro river basin.

Thermal studies, with elemental analysis, indicate the presence of fossilized organic carbon within clay particles of the flooded soil, which only decomposed above $800^{\circ} \mathrm{C}$. This finding could explain the different thermal stability and activation energy required for pyrolysis of Iara (flooded) HS compared to Araçá (non-flooded) HS.

\section{Acknowledgments}

The authors are indebted to CAPES, FAPESP and CNPq (Brazilian agencies) for their financial support.

\section{References}

1. Sheng, G. P.; Zhang, M. L.; Yu, H. Q.; J. Colloid Interface Sci. 2009, 331, 15.

2. Romão, L. P. C.; Lead, J. R.; Rocha, J. C.; Oliveira, L. C.; Rosa, A. H.; Mendonça, A. G. R.; Ribeiro, A. S.; J. Braz. Chem. Soc. 2007, 18, 714 .

3. Bayer, C.; Martin-Neto, L.; Mielniczuk, J.; Saab, S. C.; Milori, D. M. B. P.; Bagnato, V. S.; Geoderma 2002, 105, 81.

4. He, Z.; Ohno, T.; Wu, F.; Olk, D. C.; Honeycutt, W.; Olanya, M.; Soil Sci. Soc. Am. J. 2008, 72, 1248.

5. Margherita, E.; Brunetti, G.; Garcia Isquierdo, C.; Cavalcanti, F.; Fiore, S.; Senesi, N.; Soil Sci. 2006, 171, 322.

6. Oliveira, L. C.; Sargentini,Jr., E.; Rosa, A. H.; Rocha, J. C.; Simões, M. L.; Martin-Neto, L.; Silva, W. T. L.; Serudo, R. L.; J. Braz. Chem. Soc. 2007, 18, 860.

7. Martin-Neto, L.; Rosell, R.; Sposito, G.; Geoderma 1998, 81, 305.

8. Leinweber, P.; Schulten, H. R.; Thermochim. Acta. 1992, 200, 151.

9. Rosa, A. H.; Rocha, J. C.; Furlan, M.; Quim. Nova 2000, 23, 472.

10. Rosa, A. H.; Oliveira, L. C.; Bellin, I. C.; Rocha, J. C.; Dias Filho, N. L.; Thermochim. Acta. 2005, 433, 77.

11. Flynn, J. H.; Wall, J.; Polym. Lett. 1996, 4, 323.

12. Ozawa, T.; Bull Chem. Soc. Jpn. 1965, 38, 1881.

13. Ozawa, T.; J. Therm. Anal. 1970, 2, 301.

14. Ozawa, T.; Polymer 1971, 12, 150.

15. Weil, J. A.; Bolton, J. R.; Electron Paramagnetic Resonance: Elementary Theory and Practical Applications, Wiley: New York, 1994. 
16. Poole, C. P.; Farach, H. A.; Theory of Magnetic Resonance, Wiley: New York, 1972.

17. Singer, L. S.; J. Appl. Physiol. 1959, 30, 1463.

18. Martin-Neto, L.; Andriulo, A. E.; Traghetta, D. G.; Soil Sci. 1994, 157, 365.

19. Wershaw, R. L.; Environ. Sci. Technol. 1993, 27, 814.

20. Piccolo, A.; Soil Sci. 2001, 166, 810.

21. Chen, Y.; Senesi, N.; Schnitze, M. R; Soil Sci. Soc. Am. J. 1977, $41,352$.

22. Ikeya, K.; Yamamoto, S.; Watanabe, A.; Org. Geochem. 2004, 35,583 .
23. Serudo, R. L.; Oliveira, L. C.; Rocha, J. C.; Paterlini, W. C.; Rosa, A. H.; Silva, H. C.; Botero, W. G.; Geoderma 2007, 138, 229.

24. Swift, R. S.; Methods of Soil Analysis, Madison: New York, 1996

25. Rosa, A. H.; Simões, M. L.; Oliveira, L. C.; Rocha, J. C.; Martin Neto, L.; Milori, D. M. B. P.; Geoderma 2005, 127, 1.

Received: March 16, 2009

Web Release Date: June 26, 2009

FAPESP helped in meeting the publication costs of this article. 